\title{
PROSES DAN FUNGSI PENGIMBUHAN AWALAN KATA KERJA TERBITAN BAHASA KADAZANDUSUN: FOKUS, MASA, ASPEK, RAGAM (FMAR)
}

\author{
The Process and Function of Derived Verb Prefix in Kadazandusun Language: \\ Focus, Time, Aspect, Modal (FMAR) \\ Rozita Buyoh
rozita_gapoh@yahoo.com \\ Jane Wong Kon Ling \\ jane@ums.edu.my \\ Veronica Petrus Atin \\ vpetrus@ums.edu.my
}

Universiti Malaysia Sabah

\begin{abstract}
ABSTRAK
Bahasa Kadazandusun mula diajarkan di sekolah seawal tahun 1988 di bawah polisi pengajaran dan pembelajaran bahasa ibunda pelajar [Pupils's Own Language (POL)]. Seterusnya, pada tahun 1996 Kementerian Pendidikan Malaysia telah memperkenalkan bahasa Kadazandusun sebagai satu mata pelajaran bahasa tambahan di beberapa buah sekolah rendah terpilih di Sabah dengan mengangkat dialek Bunduliwan sebagai dialek asas pemiawaian dan pembakuan bahasa Kadazandusun. Bahasa Kadazandusun sebagai bahasa aglutinatif banyak menggunakan pengimbuhan dan penggandaan untuk menerbitkan kata baharu dari kata akar dan kata dasar. Proses pengimbuhan dalam kata kerja bahasa ini mempamerkan pola pengimbuhan yang rumit dan kompleks. Setiap bentuk imbuhan mempunyai fungsi gramatikalnya yang tersendiri. Walau bagaimanapun aspek ini belum dikaji dengan terperinci. Oleh itu, kajian ini berdasarkan kepada persoalan bagaimanakah proses pengimbuhan berfungsi untuk menandakan fokus, masa, aspek dan ragam dalam kata kerja terbitan? Kajian ini dilakukan secara kaedah lapangan melalui rakaman temu bual dengan penutur natif Dialek Bundu (DB) dan Dialek Liwan (DL) di daerah Ranau, Tambunan dan Keningau serta membuat analisis dokumen ke atas empat buah teks cerita rakyat DB dan DL. Data transkripsi rakaman dan teks cerita rakyat dianalisis untuk melihat bentuk dan paradigma pengimbuhan yang terdapat dalam kata kerja terbitan dialek yang dikaji. Hasil kajian menunjukkan bahawa DB dan DL membentuk kebanyakan kata terbitannya melalui proses penggabungan morfem kata akar, kata dasar dan kata kerja ganda dengan morfem imbuhan sama ada secara awalan, akhiran, sisipan, dan apitan. Setiap bentuk dan proses pengimbuhan tersebut mempunyai fungsi tersendiri yang menandakan fokus, masa, aspek dan ragam dalam kata kerja yang diterbitkan. Proses tersebut juga mengakibatkan perubahan kategori bagi sesetengah golongan kata dasar yang diterbitkan. Kesimpulannya, kajian ini dapat menjelaskan proses pembentukan dan fungsi pengimbuhan dalam kata kerja terbitan bahasa Kadazandusun.
\end{abstract}

Kata kunci: Bahasa Kadazadusun, proses dan fungsi pengimbuhan awalan, kata kerja terbitan, fokus, masa, aspek dan ragam

\begin{abstract}
The Kadazandusun language was first taught in schools as early as 1988 under the pupils' own language (POL) teaching and learning policies. Later, in 1996 the Ministry of Education introduced Kadazandusun as an additional language subject in several selected primary schools in Sabah with the elevation of the Bunduliwan dialect as the basic dialect of standardization and the standardization of Kadazandusun language. The Kadazandusun language as an agglutinative language has been widely used for affixation and multiplication to derive new words from root words and basic words. The affixation process of verb in this language exhibits complex patterning. Each affix form has its own grammatical function. However this aspect has not been studied in detail. Therefore, this study focuses on the question of how the process affixation functioning to mark the focus, time, aspect and variety in derivative verbs? The study was carried out on a field basis through interviews with native speakers of Dialu Bundu (DB) and
\end{abstract}


Liwan dialect (DL) in Ranau, Tambunan and Keningau districts and document analysis on four texts of DB and DL folk tales. The transcription of recording and folklore texts were analyzed to see the form and paradigm of the derivation in the verb of the studied dialect. The results show that the DB and DL form many of its derivative words through the process of merging root word morphemes, basic words and verbs with affix morphemes either by prefix, suffix, infix, and confix. Each of these forms and processes of retrieval has its own function which indicates the focus, time, aspect and variance in the verbs to be derived. The process also resulted in a category change for some of the underlying categories of derivational words. In conclusion, this study can explain the process of affixes function and forming in derivational verb of Kadazandusun language.

Keywords: Kadazandusun language, process and function of prefix, derivative verb, focus, time, aspect and variety

\section{PENGENALAN}

Bahasa Kadazandusun tergolong dalam jenis bahasa aglutinatif yang banyak menggunakan pengimbuhan dan penggandaan untuk membentuk perkataan terbitan. Sebagai bahasa yang derivatif bahasa ini membentuk kebanyakan perkataannya melalui proses pengimbuhan atau penggabungan morfem kata dasar dengan morfem imbuhan secara rentetan mendatar, iaitu imbuhan digabungkan serentak dengan kata dasar, sama ada imbuhan itu mendahului (awalan), menyisipi (sisipan), mengikuti (akhiran) atau hadir secara serentak pada awalan dan akhiran (apitan). Setiap bentuk imbuhan tersebut mempunyai fungsi gramatikal yang tersendiri untuk menandakan fokus, waktu, aspek dan ragam perbuatan. Golongan kata yang dapat membentuk kerja kerja terbitan dalam bahasa Kadazandusun terdiri dari golongan kata kerja, kata nama dan kata adjektif. Dalam kajian ini, proses pembentukan kata kerja terbitan yang dibincangkan adalah terbatas kepada pola imbuhan awalan kata kerja sahaja. Sehubungan itu, fokus kajian ini adalah untuk menghuraikan proses dan fungsi pengimbuhan awalan kata kerja yang menandakan fokus, masa, aspek, dan ragam (FMAR) yang terkandung dalam kata kerja terbitan.

\section{SOROTAN KAJIAN}

Banyak aspek berkaitan morfologi bahasa Kadazandusun belum dikaji dengan sepenuhnya. Proses dan fungsi pengimbuhan dalam menentukan fokus, sistem masa, aspek dan ragam dalam kata kerja terbitan juga belum dikaji dengan terperinci. Kajian Robinson (2005: 18 - 29) mendapati tiga bentuk fokus dalam Dusun Tindal iaitu Actor Focus (AF) yang ditandai oleh morfem -um-, mong- dan mog-; Patient Fokus (PF) yang ditandai imbuhan -on dan no-; dan Benefecative Focus (BF) yang ditandai dengan imbuhan -an dan no-. Aspek pula mempunyai dua bentuk iaitu completive aspect untuk tindakan yang telah selesai dan incompletive aspect untuk tindakan yang belum selesai dan mungkin belum bermula.

Atin (2014: 5- 9) menyatakan morfologi kata kerja dalam Bundu Dusun (BD) berpusat pada interaksi antara voice, tense dan mood system. Kajiannya turut mendapati BD mempunyai tiga bentuk simetri voice dalam kata kerja berdasarkan bentuk pengimbuhannya, iaitu Actor Voice (AV), Undergoer Voice (UV) dan Goal Voice (GV). Imbuhan moN- (AV) merujuk fokus pelaku, akhiran -on (UV) mengubah fokus kepada undergoer iaitu yang mengalami tindakan dan akhiran -an $(\mathrm{GV})$ mengubah fokus kepada penerima kesan atau tindakan. Terdapat dua bentuk mood (ragam) dalam BD iaitu default mood yang ditandai dengan imbuhan $M-$, MoN-, -um-, -on, -an; dan involuntary mood, abilitative yang ditandai dengan imbuhan ko-, ko-poN-, o-, dan o-...-an. Penanda masa dibahagikan kepada non-tensed yang menandakan imperative dan prohibitive, non-past (merujuk present atau future time) dan past bagi masa yang telah lepas.

Kamus Komoiboros Dusunkadazan (1994:xlviii-lxxxii) membahagikan kata kerja kepada tiga jenis ragam iaitu indicative, imperative dan subjuntive. Penanda masa pula terbahagi kepada present, imperfect, future simple (menerangkan perbuatan yang belum selesai) dan perfect, pluperfect dan future perfect (menerangkan perbuatan yang sudah selesai). Pengimbuhan pula dinyatakan membentuk kata kerja majmuk yang menggambarkan reciprocal, frequentative dan causative. Walau bagaimanapun tiada contoh dan huraian yang jelas berkaitan tiga bentuk ragam yang dinyatakan.

Buku Puralan Boros Kadazandusun id Sikul (2008: 13) menyenaraikan kata kerja dalam bahasa Kadazandusun mempunyai dua fungsi utama, iaitu sebagai penanda fokus dan penanda masa (tense). Penanda fokus merangkumi tiga bentuk iaitu $i$ momonsoi (pelaku) yang ditandai imbuhan awalan $m o N-; i$ noontok (mengalami tindakan) ditandai dengan imbuhan -on, -o’ dan -on; dan i monorimo (menerima 
tindakan) ditandai imbuhan akhiran -an. Penanda masa yang sudah lepas atau sudah berlalu ditandai dengan sisipan -in-, dan kata kerja yang merujuk telah selesai ditandai imbuhan no-, noko- dan no-...-an.

Kroeger (2005: 21- 36) dalam kajiannya ke atas Dusun Kimaragang (KD) menyatakan bahawa terdapat lima kategori penanda voice dalam kata kerja KD iaitu Actor Voice (AV), Objective Voice (OV), Dative Voice (DV), Instrument Voice (IV) dan Locative Voice (LV). Penanda masa dibahagikan kepada non-past yang ditandai imbuhan $m-$, -um-, -on, -an, $i$ - dan -on; past ditandai imbuhan $m$-in- / -in-um-, in-__ $\varnothing$, -in-__an, n-i- dan -in-__on. Mood pula dibahagikan kepada imperativel subjunctive yang ditandai imbuhan -o/, -ai dan potentive yang ditandai imbuhan (no)ko-, (n)o-, dan (n)o- -an.

Dahl (1985); Payne (2001: 238-244); Kroeger (2005: 158-163) menyatakan aspek mempunyai dua kategori utama iaitu perfective vs imperfective. Perfective merupakan kategori aspek yang merujuk keseluruhan kejadian dan bebas dari aspek masa. Manakala imperfective pula dibahagikan kepada dua jenis iaitu progressive dan habitual. Asmah (2009: 120) menghuraikan bahawa kata kerja aspek merujuk kepada proses perbuatan atau keadaan sama ada belum, masih atau selesai berlaku. Kata kerja aspek pula mempunyai hubungan yang erat dengan konsep waktu, yakni waktu perbuatan atau keadaan berlaku dan ditandai oleh kata kerja bantu iaitu sudah, telah, dan pernah untuk merujuk perbuatan yang telah berlaku; sedang, masih, tengah menunjuk perbuatan atau keadaan yang sedang berlaku dan ; belum dan akan menunjuk perbuatan yang belum berlaku. Kata kerja modalitas pula membantu dalam memberi ciri 'suasana' kepada perbuatan atau keadaan yang dirujuk oleh kata kerja leksikal dan untuk menerangkan kehendak, keupayaan atau keizinan, kemestian, kebarangkalian atau kemungkinan, keengganan dan keperluan Asmah (2009: 126).

\section{METODOLOGI}

Kajian ini dilakukan secara kaedah lapangan melalui rakaman temu bual tidak berstruktur dengan penutur natif Dialek Bundu (DB) dan Dialek Liwan (DL) di daerah Ranau, Tambunan dan Keningau. Selain itu, penyelidik membuat analisis dokumen ke atas enam buah teks cerita rakyat DB dan DL. Data transkripsi rakaman dan teks cerita rakyat dianalisis untuk melihat bentuk paradigma pengimbuhan yang terdapat dalam kata kerja terbitan dialek yang dikaji.

Data dianalisis berdasarkan pola dan bentuk pengimbuhan awalan kata kerja dalam kata kerja tunggal dan kata kerja terbitan. Fokus terdiri daripada Fokus Aktor (FA), Fokus Objek (FO), Fokus Penerima (FP), dan Fokus Lokasi (FL) yang ditentukan berdasarkan bentuk imbuhan yang diterima. Penanda masa ditandai sama ada sudah lepas, masa kini atau masa akan datang. Ciri non-tensed (N-T) adalah merujuk aspek masa yang neutral dan tidak spesifik waktunya iaitu sama ada sudah lepas, masa kini atau akan datang.

Kategori aspek ditandai sama ada perbuatan sudah selesai, progresif (merujuk sedang berlaku), habitual (merujuk kekerapan) atau akan berlaku. Ragam pula ditandai sama ada imperative (kehendak), subjunctive (kebarangkalian atau kemungkinan) dan potentive (potensi atau keupayaan).

\section{DAPATAN KAJIAN DAN PERBINCANGAN}

\section{Proses Pengimbuhan Awalan dan Analisis FMAR dalam Kata Kerja Terbitan Bahasa Kadazandusun}

Pembentukan kata kerja melalui pengimbuhan awalan melibatkan imbuhan o/a-, ongo-/anga-, $n-$, no-/na-, ko-/ka-, noko-/naka-, m-, mi-, miN-, moN-/ maN, moM-/-/maM-, poN-/paN-, poiN-, poki-, moki-dan mogi-. Setiap bentuk imbuhan mempunyai fungsi tersendiri dalam menentukan fokus, masa, aspek, ragam (FMAR) yang terdapat dalam kata kerja tersebut. Bentuk imbuhan yang sama juga boleh membawa beberapa makna dan konsep yang berbeza bergantung kepada kata dasar yang mengikutinya.

\section{Imbuhan o-/a-, ongo-/anga-, n-, no-/na-, ko-/ka-, noko-/naka-}

Proses pengimbuhan awalan o-/a-, ongo-/anga- melibatkan penggabungan kata kerja tunggal yang bermula dengan huruf vokal dan huruf konsonan. Perbezaan utama antara keduanya adalah dari aspek penanda kekerapan perbuatan. Bagi imbuhan $o-/ a$ - jumlah yang dirujuk lazimnya merujuk sekali 
perbuatan sahaja kepada satu objek sasaran. Imbuhan ongo-/anga- pula merujuk makna jamak atau semua serta menjadi penanda kekerapan perbuatan. Proses pengimbuhan dan penggunaan perkataan dalam ayat dapat dilihat seperti contoh di bawah:

$$
\begin{array}{lll}
o-+ \text { kito } & - & \text { okito (dapat dilihat) } \\
\text { a- + tagad } & - & \text { atagad (dapat ditebang) } \\
\text { a- + patai } & - & \text { apatai (mati, kering) } \\
\text { ongo- }+ \text { sonsog } & - & \text { ongosonsog (semua memaksa) } \\
\text { ongo- }+ \text { tiil } & - & \text { ongotiil }(\text { semua nakal) } \\
\text { anga- }+ \text { pandai } & - & \text { angapandai }(\text { semua tahu) }
\end{array}
$$

(i) Dotuong di norongou di Yoropod do mingusig tomod i Simpou nga au disio okito om nunu usigon tu rondom tomod. B83 BCR DL (i)

(Malam itu Yoropod terdengar Simpou asyik menyalak tetapi dia tidak dapat melihat apa yang disalaknya kerana malam sangat gelap.)

(ii) Atagad nondo i kayu di hom soira do it apatai okoring it kayu di angagayo di angatagad di om tutudan nondo om soludan po kagu ri do sebelum do tutudan. B28 RNU 04/DB (L) (Selepas kayu ditebang, kayu yang besar yang ditebang mati dan kering barulah dibakar dan dibuat upacara bacaan mantera sebelum membakar.)

(iii) "Yondo nopo tu' ongosonsog om ongotiil tomod kou..." B25 BCR DB (4)

(Oleh sebab kamu sangat memaksa dan kamu sangat nakal..."

(iv) Angapandai tod do Dusun ih Sama. B73 TBN 6/DB (L)

(Orang Sama itu semuanya sangat pandai berbahasa Dusun.)

Awalan $n$ - melibatkan penggabungan kata kerja tunggal yang bermula dengan huruf vokal. Imbuhan $n$ - menandakan sekali perbuatan ke atas satu objek. Sementara imbuhan no-/na-boleh bergabung dengan kata dasar yang bermula dengan huruf vokal atau konsonan tanpa melibatkan sebarang pengguguran huruf. Awalan no-/na- menandakan makna keupayaan serta merujuk perbuatan tanpa sengaja. Proses pengimbuhan dan contoh penggunaan dalam ayat adalah seperti yang berikut:

$$
\begin{array}{lll}
n-+ \text { ihum } & - & \text { nihum (dicari) } \\
n-+ \text { owit } & - & \text { nowit (dibawa) } \\
\text { no }-+ \text { rulun } & - & \text { norulun (telah hanyut) } \\
\text { na }- \text { palid } & - & \text { napalid (telah tersesat) } \\
\text { na }-+ \text { anu } & - & \text { naanu (dapat diambil) } \\
\text { na }- \text { awi } & - & \text { naawi (habis) }
\end{array}
$$

(i) Om aih di nihum tontok pod diri. B131 RNU 03/DB (P)

(Dia tidak dicari pada masa itu.)

(ii) Nowit ku nopo nga solopot ih kopiyo takano nowitku. B18 KGU 03/DL (P)

(Yang saya bawa pada masa itu hanyalah sebungkus nasi sahaja.)

(iii) Iso noh boh tulun do norulun di toruhai po. B249 TBN 01/DL (P)

(Sudah seorang mangsa yang hanyut baru-baru ini.)

(iv) Oo napalid yolo om kaa di yolo hilo Kudat. B20 RNU 02/DB (L)

(Mereka telah sesat lalu mereka pergi ke Kudat.)

(v) Nu pod'di o naanu naawi. Jadi, ingga di bo dogo ti tana. B116 KGU 03/DL (P)

(Tiada dapat apa-apa lagi sebab sudah habis. Jadi, saya ini tiada tanah.) 
Fokus imbuhan bagi o-/a-, ongo-/anga-, $n$ - dan no-,/na adalah FO iaitu objek yang menjadi sasaran perbuatan. Awalan o-/a-, ongo-/anga- adalah merujuk masa kini, akan datang dan aspeknya sedang atau akan berlaku. Imbuhan $n-, n o-/ n a-$ pula menandakan masa lepas dan aspek sudah berlaku dan sudah selesai. Ragam imbuhan ini merujuk potensi atau keupayaan serta perbuatan tanpa sengaja.

Proses pengimbuhan $\mathrm{ko}-\mathrm{ka}$, noko-/naka- bergabung dengan kata dasar yang bermula dengan huruf vokal dan konsonan. Imbuhan ini mempunyai fungsi yang sama iaitu menandakan makna ability atau keupayaan mencapai sasaran; dan makna accidental iaitu ter- atau tanpa sengaja. Proses pengimbuhan kedua-dua bentuk dan contoh penggunaan dalam ayat dapat dilihat dalam contoh di bawah:

$\begin{array}{lcl}\text { ko- }+ \text { ongoi } & - & \text { koongoi (dapat mengambil) } \\ \text { ko- + wonsoi } & - & \text { kowonsoi (dapat menyiapkan) } \\ \text { ka- }+ \text { sanganu } & - & \text { kasanganu (dapat memiliki) } \\ \text { ko- + tompisal } & - & \text { kotompisal (tergelincir) } \\ \text { ko- }+ \text { likad } & - & \text { kolikad (terseliuh) } \\ \text { naka- }+ \text { waliu } & - & \text { nakawaliu (telah berpindah) } \\ \text { noko- }+ \text { ampai } & - & \text { nokougus (telah menghilir) }\end{array}$

(i) Koongoi ko nopo sansaan om kowonsoi no tugu lo adi torilis. B119 TBN 04/DL (P)

(Jika kamu dapat mengambil sebatang bambu sudah cukup untuk dibuat sekeping tikar kecil seperti itu.)

(ii) Kotompisal om kolikad no lapap disido. B139 BCR DB (2)

(Dia tergelincir lalu kakinya terseliuh.)

(iii) Yoku nopo daa kasanganu nga ounsikou oku no daa. B130 BCR DL (5)

(Jika saya yang dapat memiliki alangkah gembiranya saya.)

(iv) Oo. Au nod'di yolo nakawaliu do hilo. Jadi, ih Runsud nopo ti nga nokougus diti Liwogu. B28 RNU 02/DL (L)

(Ya. Mereka tidak lagi berpindah dari sana. Jadi Runsud pula telah menghilir di sungai Liwogu.)

Fokus bagi kedua-dua jenis imbuhan adalah FA. Masa dan aspek bagi awalan yang dirujuk bagi ko-/ka- adalah masa kini dan sedang berlaku, manakala awalan noko-/naka- menandakan masa dan aspek yang sudah lepas dan sudah selesai. Ragamnya adalah sama iaitu merujuk potensi atau keupayaan.

\section{Imbuhan $m-$, mi-, miN-}

Imbuhan $m$ - bergabung dengan kata kerja tunggal yang bermula dengan huruf vokal sahaja. Imbuhan ini berfungsi menandakan aksi atau perbuatan pelaku yang berkaitan arah pergerakan dan lokasi. Imbuhan $m i$ - bergabung pada kata dasar yang bermula dengan huruf vokal dan konsonan dan berfungsi menandakan perbuatan yang saling berbalas antara dua orang pelaku sahaja. Awalan miN-mempunyai tiga varian iaitu, min-, ming- dan mim-. Varian min- bergabung pada kata kerja tunggal yang bermula dengan huruf konsonan sedangkan varian ming- bergabung dengan kata dasar yang bermula dengan huruf vokal dan konsonan. Varian mim- pula bergabung dengan konsonan /p/ dan /b/. Varian min-, ming- dan mim- berfungsi menandakan makna kekerapan perbuatan yang berterusan ke atas diri sendiri, objek atau pun ke atas orang lain. Proses pengimbuhan dan contoh penggunaan perkataan dalam ayat adalah seperti berikut:

$$
\begin{array}{lll}
\text { m- }+ \text { ion } & - & \text { mion (menetap) } \\
m-+ \text { umboyo } & - & \text { mumboyo (bersetuju, akur) } \\
\text { mi- + sokodung } & - & \text { misokodung (bekerjasama) } \\
\text { min- }+ \text { tondig } & - & \text { mintondig (menyanyi) } \\
\text { ming- }+ \text { intong } & - & \text { mingintong (melihat, memerhati) }
\end{array}
$$


ming- + koili $\quad-\quad$ mingkoili (menoleh)

mim- + puhu - mimpuhu (mengutip)

mim- + boros - mimboros (bercakap)

(i) Okon ko mion do hilo. B66 KGU 04/DL (L)

(Bukannya menetap di sana.)

(ii) “Oo no, mumboyo oku nopo," ka di sumandak. B141 BCR DL (5)

("Baiklah, saya setuju sahaja," kata gadis itu.)

(iii) Polis Sabah om Brunei misokodung karaja manamong kotingoligan. B4 BD/02 (RTM)

(Polis Sabah dan Brunei berkerjasama dalam menjaga keselamatan.)

(iv) Mintondig nodii kaka Goroi do monginsasamod di tanak. B28 BCR DL (3)

(Goroi menyanyi untuk memujuk anaknya)

(v) Mingio ku po lo'd hait mingintong nga hiti gia siba iti om ai di kokito lo Nabalu boh. Jadi mingkoili tomod oku ai di haro kapal tarabang. B254 RNU 05/DB (L)

(Saya berusaha untuk memerhati tetapi tempat ini di bawah dan tidak dapat melihat gunung Kinabalu. Jadi saya menoleh ke sana sini tetapi tiada kelihatan kapal terbang.)

(vi) Logot-logoto' no dau do mimpuhu di parai. B92 BCR DL (3)

(Lalu dia pun mengutip padi itu satu-persatu.)

(vii) Nga ih di tinu di nga osusa moti ri mimboros. B147 KGU 03/DL (P)

(Yang tadi itu pun susah untuk bercakap Dusun.)

Kesemua awalan $m$-, mi- dan $m i N$ - menandakan FA dan masa yang dirujuk adalah masa kini dengan aspek sedang berlaku. Berdasarkan fungsinya imbuhan tersebut menandakan ragam aktif, reciprocal, iaitu perbuatan menyaling dan habitual, iaitu berulang-ulang.

\section{Imbuhan $\mathrm{moN}-/ \mathrm{maN}-, \mathrm{moM}-/ \mathrm{maM}-, \mathrm{mob}-/ \mathrm{mod}-/ \mathrm{mad}-$}

Imbuhan moN- mempunyai tiga varian, iaitu mon-, mong-, dan mog. Varian maN- pula adalah man-, mang- dan mag-. Imbuhan mon-/man- bergabung dengan kata dasar yang bermula dengan huruf konsonan dan huruf awal perkataan digugurkan. Imbuhan mong-/mang dan mog-/mag- pula bergabung dengan kata dasar yang bermula dengan huruf vokal dan tiada penguguran huruf berlaku. Awalan $\mathrm{mob}-/ \mathrm{mod}-/ \mathrm{mad}-$ bergabung dengan perkataan yang bermula dengan konsonan $/ \mathrm{p} /, / \mathrm{s} /$, dan $/ \mathrm{t} /$ pengimbuhannya tidak melibatkan pengguguran huruf pada kata dasar. Imbuhan ini berfungsi untuk menerangkan aktiviti atau pekerjaan yang dilakukan serta menandakan ragam aktif. Proses pengimbuhan dan contoh penggunaan perkataan adalah seperti berikut:

$$
\begin{array}{lcl}
\text { mon- }+ \text { tidong } & - & \text { monidong (berhuma) } \\
\text { man- }+ \text { tahak } & - & \text { manahak (memberi) } \\
\text { mang- + anit } & - & \text { manganit (mengupas kulit) } \\
\text { mong- }+ \text { uhup } & - & \text { monguhup (membantu) } \\
\text { mog- }+ \text { ihum } & - & \text { mogihum (mencari) } \\
\text { mag- }+ \text { andad } & - & \text { magandad (menunggu) }
\end{array}
$$

(i) Manganit nogi matu ih timpuunon. B86 TBN 04/DL (P)

(Permulaan adalah membuka kulit.)

(ii) Nokoumbal oku poh miakil-akil do monidong. Adi tanak ku gulu'. B16 TBN 04/DL (P)

(Saya pernah mengerjakan huma sambil menyikut anak sulung saya.) 
(iii) Amu nodi yahai kaanu do manahak do kounsikahan do kumaa id dika tu' nolohing no yahai. B160 BCR DL (5)

(Kami tidak mampu lagi memberi kegembiraan kepada kamu sebab kami sudah tua.)

(iv) Aiso tanak do monguhup do kumaraja. B54 BCR DL (5)

(Tiada anak yang membantu bekerja.)

(v) Jadi osusa id'di dot mogihum do balanja do tanganak boh. B30 RNU 06/DL (L)

(Jadi susah untuk mencari duit belanja anak-anak.)

(vi) Diom aasakan om magandad nodi di sakot sumurut. B30 TBN 04/DL (P)

(Selepas padi disemai tinggal menunggu rumput tumbuh.)

Varian imbuhan moM-/maM termasuklah mom-/mam, momo-/mama-; momu-, dan momi-. Imbuhan ini menjadi penanda aktif. Semua varian ini hanya bergabung dengan kata dasar yang bermula dengan huruf konsonan. Hanya varian mom-/mam- yang mengakibatkan pengguguran pada huruf awal kata dasar dan varian yang lain tidak menyebabkan sebarang pengguguran huruf. Proses pembentukan dan contoh penggunaan setiap varian dapat dilihat dalam contoh di bawah:

$\begin{array}{lll}\text { mom- }+ \text { boli } & - & \text { momoli (membeli) } \\ \text { mam- + panau } & - & \text { mamanau (berjalan kaki) } \\ \text { momo- + himbaan } & - & \text { momohimbaan (membersihkan hutan) } \\ \text { mama- + langga } & - & \text { mamalangga (membersihkan) } \\ \text { momu- + tanom } & - & \text { momutanom (bertani) } \\ \text { momi- + rangkat } & - & \text { momirangkat (memunggah) }\end{array}$

(i) Kiniat ko nopo momoli karabau om moi Kota Belud. B200 RNU 05/DB (L)

(Jika kamu berniat untuk membeli kerbau pergilah ke Kota Belud.)

(ii) Om mamanau di gakod di gulu. B66 KGU 01/DB (P)

(Berjalan kaki sahaja pada masa dahulu.)

(iii) Ih momohimbaan dit mamalangga dit o mamalangga do gouton. B198 RNU 04/DB (L)

(Menebang kayu untuk membersihkan hutan belukar.)

(iv) Aa' yahai koinum di kupi aa' yahai koilo momonsoi. Momutanom noh. B84 TBN 02/DB (P)

(Kami tidak dapat minum kopi sebab kami tidak tahu cara memprosesnya. Kami hanya menanamnya.)

(v) Nosorou ku nopo nga ih nondo ti Guraim i ti Gibah ih nosorou ku momirangkat do parai. B4 TBN 02/DB (P)

(Yang saya ingat ialah si Guraim dan si Gibah yang saya ingat memunggah padi.)

Fokus bagi kesemua bentuk awalan di atas adalah FA. Masa yang dirujuk adalah masa kini atau akan datang. Aspek yang ditunjukkan pula sama ada sedang berlaku atau akan berlaku. Ragam yang ditunjukkan adalah potensi iaitu keupayaan dan imbuhan ini juga menandakan bentuk aktif.

\section{Imbuhan poN-/paN-, poiN-}

Imbuhan awalan poN-/paN- mempunyai beberapa varian iaitu po-, pon-, pong-, pog-/ pa-, pan-, pang, pag. Imbuhan ini berfungsi menandakan perbuatan menjadikan, menyebabkan atau kausatif. Imbuhan poIpa- bergabung dengan kata dasar bermula dengan vokal dan konsonan dan penggabungannya tidak 
melibatkan sebarang pengguguran huruf. Imbuhan pon-/pan-, pong-/pang- bergabung dengan kata dasar yang bermula dengan konsonan dan setiap huruf awal digugurkan. Imbuhan pong-/pang- dan pog-/pagjuga bergabung dengan kata dasar yang bermula dengan huruf vokal dan penggabungannya tidak melibatkan pengguguran huruf pada kata dasar. Proses pengimbuhan dan contoh penggunaan dalam ayat adalah seperti yang berikut:

$\begin{array}{lcl}\text { po- }+ \text { lisok } & - & \text { polisok (menyembunyikan) } \\ \text { pa- + sasad } & - & \text { pasasad (menabur) } \\ \text { pong- }+ \text { uhup } & - & \text { ponguhup (membantu) } \\ \text { pang- }+ \text { alap } & - & \text { pangalap (menjemput) } \\ \text { pog- }+ \text { idu } & - & \text { pogidu (lari, pergi) } \\ \text { pag- }+ \text { anu } & - & \text { paganu (mengambil) }\end{array}$

(i) Ih no'it moi polisok o parai osorou ku. B2 TBN 02/DB (P)

(Peristiwa semasa pergi menyembunyikan padi sahaja yang saya ingat.)

(ii) Pasasad wagu, baja wagu. B208 KGU 04/DL (L)

(Menabur lagi, baja lagi.)

(iii) Isai maa dii o tulun do minongoi ponguhup dato? B58 BCR DL (5)

(Siapakah orang yang telah pergi menolong kita?)

(iv) Haro songulun do suhuon di moi pangalap. B134 RNU 05/DB (L)

(Ada seorang yang disuruh untuk pergi menjemput.)

(v) “Nga osonong dot pogidu kou koti," ka. B68 RNU 02/DL (L)

("Tetapi lebih baik kamu pergilah," katanya.)

(vi) Poiliho' no di Yanakanak i tapon dau om lintuhun no do minongoi paganu di kakanan id tanga do bawang. B76 BCR DL (5)

(Yanakanak meletakkan pancingnya lalu turun pergi mengambil tajau di tengah sungai itu.)

Fokus dalam imbuhan $p o N-/ p a N$ - adalah FA. Masanya adalah neutral iaitu boleh merujuk masa lalu, masa kini atau masa akan datang. Aspeknya pula adalah sama ada telah, sedang, belum atau akan berlaku. Ragamnya merujuk potensi dan keupayaan serta merujuk kausatif atau menyebabkan.

Imbuhan poiN- pula mempunyai tiga varian, iaitu poin-, poim-, dan poing-. Awalan poiNberfungsi menandakan perbuatan yang merujuk posisi atau lokasi. Imbuhan poin- bergabung dengan kata dasar yang bermula dengan konsonan dan imbuhan poing- bergabung dengan kata dasar bermula dengan huruf vokal. Imbuhan poim- pula hanya bergabung dengan kata dasar yang bermula dengan huruf konsonan /b/ dan /p/ dan setiap varian tidak melibatkan pengguguran huruf pada awal kata dasar. Proses pengimbuhan dan contoh dapat dilihat seperti di bawah:

$$
\begin{array}{lll}
\text { poin- }+ \text { tanom } & - & \text { pointanom (tertanam) } \\
\text { poim- }+ \text { babo } & - & \text { poimbabo (disikut) } \\
\text { poing- }+ \text { ulok } & - & \text { poingulok (memijak) } \\
\text { poing- }+ \text { igit } & - & \text { poingigit (memegang) }
\end{array}
$$

(i) Pointanom pondo moturu mantad diri. B72 TBN 01/DL (P)

(Mungkin sudah sedia tertanam.)

(ii) Tinorobong o toyoon sagai. Oroi, poimbabo po tanak om! B67 TBN 04/DL (P)

(Kami pergi menimba air di perigi. Aduh, sambil menyikut anak lagi.)

(iii) Lapap poingulok do tana poingigit do sarapang pangakai do rinomos. B103 BCR DB (2) 
(Tapak kakinya memijak tanah sambil memegang pencakar untuk membersihkan sampah.)

Fokus yang dirujuk adalah FL iaitu posisi atau lokasi. Masa yang dirujuk adalah masa lepas dan masa kini dengan aspek sudah berlaku atau progresif. Ragam yang dirujuk adalah potensi atau keupayaan.

\section{Imbuhan moki-/poki-, mogi-}

Imbuhan moki- , poki- membawa makna permintaan dan imbuhan ini bergabung dengan kata dasar yang bermula dengan huruf vokal dan konsonan. Pengimbuhan tidak menggugurkan huruf awal pada kata dasar. Imbuhan mogi- berfungsi menandakan jumlah jamak, iaitu perbuatan menyaling atau bersama-sama melebihi tiga orang pelaku. Imbuhan ini turut bergabung dengan kata dasar bermula huruf vokal dan konsonan. Proses pengimbuhan dan contoh penggunaanya dalam ayat dapat dilihat seperti berikut:

$$
\begin{array}{lll}
\text { moki- }+ \text { susui } & - & \text { mokisusui (minta diceritakan) } \\
\text { moki- + anu } & - & \text { mokianu (meminta) } \\
\text { poki- + anu }- & \text { pokianu (meminta) } \\
\text { poki- }+ \text { susui }- & \text { pokisusui (minta diceritakan) } \\
\text { mogi- }+ \text { olon - } & \text { mogiolon (bertukar-tukar) } \\
\text { mogi- + sowoli }- & \text { mogisowoli (berganti-ganti) }
\end{array}
$$

(i) Jadi ongoi dit Gunting Lagadan soloot do hilo Kiau lo pokisusui ngai di wayaan om mokisusui ngai om nunu ngai maan pakayo di moi hilo Nabalu. B104 RNU 05/DB (L)

(Jadi Gunting Lagadan telah berjumpa dengan orang Kiau tersebut untuk meminta penerangan tentang laluan dan minta penjelasan tentang peralatan dan keperluan yang digunakan untuk mendaki gunung Kinabalu.)

(ii) Yoho nga nokoumbal oku da nakanu oku mokianu kawan dot mantad id Tanom o bibit. B142 RNU 06/DL (L)

(Saya pun pernah dapat benih, saya meminta benih dari kawan di Tenom.)

(i) Yoho nga monongkounsikou oku nogindo do nokorikot kou hiti do mooi pokianu diti susuian dong gulu-gulu tu aa' nopondo haro o mooi pokisusui ti hom ai osusui do gisom. B275 RNU 04/DB (L)

(Saya pun turut gembira atas kedatangan kamu ke mari untuk meminta cerita tentang kisah di sini pada masa dahulu kerana jikalau tiada yang ingin mengetahuinya kisah itu tidak akan diceritakan sampai bila-bila.)

(iii) Masa nopo dit mogiolon kou di barang om nu bahasa dokou di Sama? B72 TBN 6/DB (L)

(Semasa kamu bertukar-tukar barang apa bahasa yang kamu gunakan apabila bercakap dengan orang Sama?)

(i) Noumbalan no ngawi di Rokian o rusapan om mogisowoli o bobolian naalap manakul nga au nolingasan i Bulantoi di tomporuol disido. B14 BCR DL (1)

(Rokian pernah cuba pelbagai ubatan dan berganti-ganti bomoh dipanggil untuk mengubat tetapi Bulantoi tidak sembuh dari penyakitnya.)

Fokus yang dirujuk dalam setiap awalan tersebut adalah FA. Awalan moki- dan mogi- merujuk masa masa kini dan aspeknya sedang berlaku. Awalan poki- pula merujuk masa dan aspek yang neutral. Ragamnya bagi moki-,/poki- adalah imperative atau kehendak sedangkan awalan mogi- merujuk ragam reciprocal atau perbuatan menyaling. 


\section{Proses dan Peringkat Pengimbuhan Menentukan sama ada Imbuhan Awalan atau Sisipan}

Bagaimanakah untuk menentukan sama ada imbuhan yang terdapat dalam perkataan seperti minongowit, minogihum, pinoilo, pinolombus, dan minodop bukannya awalan mino-/pino-, tetapi sebaliknya merupakan sisipan <in>? Bentuk imbuhan perkataan tersebut dapat ditentukan dengan kaedah menganalisis peringkat pengimbuhan yang bergabung dengan kata dasar.

Data kajian ini menunjukkan bahawa imbuhan awalan miN- mempunyai tiga varian sahaja, iaitu min-, ming- dan mim- dan tiada awalan mino-/pino-. Sebagaimana dibincangkan di atas awalan ini berfungsi menandakan makna kekerapan perbuatan. Masa dan aspeknya adalah masa kini dan sedang berlaku. Varian min- hanya bergabung dengan kata kerja tunggal yang bermula dengan huruf konsonan. Sebagai perbandingan disertakan contoh proses pengimbuhan dan contoh ayat seperti di bawah:

$$
\begin{array}{lll}
\text { min- }+ \text { talib } & - & \text { mintalib (kerap melintas, melalui) } \\
\text { min- }+ \text { tulud } & - & \text { mintulud (aysik terbang) }
\end{array}
$$

(i) Waro indo boh korita mintalib di kio di musim di? B61 TBN 01/DL (P)

(Ada juga kereta yang lalu-lalang pada musim itu?)

(ii) Om ih nopo di kapal di mintulud nga don Jipun ko don British id'di? B58 TBN 5 /DB(P)

(Kapal yang terbang itu milik Jepun atau British?)

Sisipan <in> pula mempunyai dua pola utama, iaitu yang pertama sisipan <in > dengan kata kerja tunggal. Sisipan ini mendukung makna 'kena', 'di-' atau cara sesuatu perbuatan dilakukan ke atas sesuatu objek. Fokus yang dirujuk adalah FO.

$$
\begin{array}{lll}
<\text { in }>+ \text { babo } & - & \text { binabo (disikut) } \\
<\text { in }>+ \text { lopot } & - & \text { linopot (dibungkus) } \\
<\text { in }>+ \text { lisok } & - & \text { linisok (disembunyikan) }
\end{array}
$$

(i) Pomoli nopondo dahai sada Oyo nga i wagas do binabo da. B89 TBN 5 /DB(P)

(Oyo, yang kami guna untuk membeli ikan adalah beras yang kami sikut.)

(ii) Oo' linopot. Jadi berwakid-wakid ih takano dit timungon dot untuk dot takanon di tulun korikot moi intong di kawin. B128 RNU 01/DL (P)

(Ya nasi dibungkus daun. Jadi berbakul-bakul nasi bungkus yang disediakan untuk dihidangkan kepada tetamu yang hadir dalam majlis perkahwinan.)

(iii) Amu di Goroi oilaan o sanganu di gonob di linisok dau. B7 BCR DL (3)

(Goroi tidak mengetahui siapa pemilik kain sarung yang disembunyikannya.)

Bentuk atau pola yang kedua adalah sisipan <in> dengan kata kerja terbitan yakni kata dasar tersebut bermula dengan fonem $/ \mathrm{m} /$ atau fonem $/ \mathrm{p} /$. Imbuhan ini berfungsi menandakan perbuatan pelaku ke atas objek atau sasaran. Pola inilah yang menghasilkan sekan-akan wujudnya awalan mino- dan pino-. Sebaliknya, data memaparkan bahawa imbuhan tersebut merupakan sisipan 〈in > yang menyisipi kata kerja terbitan untuk menandakan kala atau masa lepas dan aspeknya sudah selesai. Proses penyisipan dan contoh penggunaan perkataan dalam ayat dapat dilihat seperti yang berikut:

$$
\begin{aligned}
& <\text { in }>+ \text { mongowit }[\mathrm{moN}-+ \text { owit }] \\
& <i n>+ \text { mogihum }[\text { mog- }+ \text { ihum }] \\
& <i n>+ \text { manahak }[\text { maN }-+ \text { tahak }] \\
& <i n>+ \text { momuhu }[\text { moM- }+ \text { puhu }] \\
& <i n>+ \text { poilo } \quad[\text { po- }+ \text { ilo }]
\end{aligned}
$$

- minongowit (telah membawa)

- minogihum (telah mencari)

- minanahak (telah memberi)

- minomuhu (telah mengutip)

- pinoilo (diberitahu) 


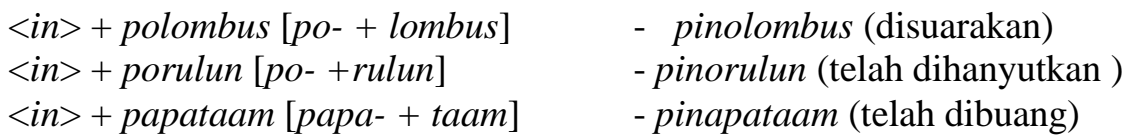

(i) Au ku nogi di nokoilo nung waro minongowit nga kosorou ku nopo'm ogumu noh poring songintanom. B74 TBN 01/DL $(P)$

(Saya pun tidak tahu jika ada yang telah membawanya tetapi seingat saya memang banyak bambu yang tumbuh sediakala.)

(ii) Jadi iri nopo di ketua diolo di nga minogihum pogun suai? B11 RNU 02/DB (L)

(Jadi ketua mereka itu telah mencari petempatan baru?)

(iii) Om isai ot minanahak di bibit do kupi? B85 TBN 02/DB (P)

(Jadi siapa yang telah memberi benih kopi?)

(iv) Kokito no di boyoon om poboros no, "Atukoi, om oruhai ko no kopio do minomuhu dilo parai!" B96 BCR DL (3)

(Apabila ketua melihatnya dia berkata, "Wah, cepat sungguh kamu mengutip biji padi itu!")

(v) Amu di Yanakanak pinoilo i Kinombura kokomoi do kakanan do kisuang do tangkayau dii. B80 BCR DL (5)

(Yanakanak tidak beritahu kepada Kinombura tentang tajau yang berisi seketul hai tersebut.)

(vi) Soira do pinolombus di Kaki o suang do ginawo dau kumaa di Kodu, om ounsikou tomod o ginawo di Kodu tu' haro kasari muhang dau. B9 BCR DL (5)

(Apabila Kaki menyuarakan isi hatinya kepada Kodu, Kodu sangat gembira kerana ada orang yang mencintainya.)

(vii) Yoku nopo nga tanak di Kodu om i Kaki nga pinorulun oku diolo tu' oikuman do kitanak do tangkayau. B139 BCR DL (5)

(Saya ialah anak Kodu dan Kaki tetapi saya telah dihanyutkan kerana mereka malu mempunyai anak yang hanyalah seketul hati.)

(viii) Oikuman tomod yolo do pinapataam do tanak sondii. B154 BCR DL (5)

(Mereka berasa sangat malu kerana telah membuang anak sendiri.)

Fokus yang dirujuk dalam sisipan $\langle i n>$ dalam kata terbitan adalah FA iaitu aktor atau pelaku. Walau bagaimanapun kedua-dua bentuk sisipan $\langle i n\rangle$ adalah merujuk masa lepas dengan aspeknya telah selesai. Ragam yang ditunjukkan merupakan potensi dan keupayaan.

\section{KESIMPULAN}

Berdasarkan perbincangan di atas jelas bahawa pola dan proses pengimbuhan awalan yang berlaku dalam kata kerja terbitan bahasa Kadazandusun mempunyai fungsinya yang tersendiri bagi menerangkan fokus, masa, aspek dan ragam. Bentuk pengimbuhan dalam bahasa ini yang dikatakan kompleks dan berlapislapis juga dapat dianalisis berdasarkan pola peringkat dan bentuk pengimbuhan yang berlaku. Analisisnya perlu bermula dengan peringkat yang paling asas, iaitu pengimbuhan kata kerja tunggal, seterusnya peringkat peluasan atau penerbitan semula kata dasar membentuk kata kerjaa terbitan yakni proses yang boleh berulang sehingga beberapa peringkat. Fokus, masa, aspek dan ragam yang ditunjukkan pula tergabung dan terjalin melalui bentuk imbuhan yang diterima oleh sesuatu kata dasar. Tuntasnya, aspek ini perlu lebih diperhalusi lagi bagi memantapkan bidang morfologi bahasa Kadazandusun terutamanya untuk kegunaan aspek pengajaran dan pembelajaran bahasa ini. 


\section{RUJUKAN}

Atin, V.P. (2011). Word classes in Bundu Dusun. Paper presented at the Fifth Asean Linguistic Conference, Dewan Bahasa dan Pustaka: Kuala Lumpur, 21-22 December 2011.

Atin, V.P. (2014). The centrality of voice system in the grammar of Bundu Dusun, International Conference on Education (ICEedu) 2014, Sekolah Pendidikan dan Kerja Sosial, UMS.

Asmah Haji Omar. (2001). Kaedah penyelidikan bahasa di lapangan. Kuala Lumpur: Dewan Bahasa dan Pustaka.

Asmah Haji Omar. (2009). Nahu Melayu mutakhir. Kuala Lumpur: Dewan Bahasa dan Pustaka.

Asmah Haji Omar. (2015). Ensiklopedia Bahasa Melayu. Kuala Lumpur: Dewan Bahasa dan Pustaka.

Chelliah Shobhana L. (2001). The role of text collection and data elicitation in linguistic fieldwork." in Newman Paul and Ratliff Martha. Linguistic Fieldwork. New York: Cambridge University Press.

Dahl, O. (1985). Tense and aspect systems. Oxford: Basil Blackwell.

Gabriel Guriting. (2014). Minan magatod. Kota Kinabalu: Bahagian Teknologi Pendidikan Sabah.

Hurlbut, H. (1988). Verb morphology in eastern Kadazan. Department of Linguistics, Research School of Pacific Studies, The Australian National University. MA: 144.

Kadazan Dusun Malay-English Dictionary. (1995). Kota Kinabalu: Kadazan Dusun Cultural Association.

Komoiboros Dusunkadazan (Dusunkadazan Dictionary). (1994). Penampang: MBDK.

Kroeger, P. (1985). Linguistic relations among the Dusunic groups in the Kota Marudu district. Borneo Research Bulletin. Vol. 17. No. 1 April 1985.

Kroeger, P. (1988). Case marking in kimaragang causative constructions. Pacific Linguistic A (78) 241-276.

Kroeger, P. (1993). Phrase structure and grammatical relations in Tagalog. California: CSLI Publications.

Kroeger, P. (1996). The morphology of affectedness in Kimaragang Dusun. Pacific Linguistic A 84 C (Papers in Austronesian Linguistics).

Kroeger, P. (2005). Kimaragang. in Sander Adelaar \& Nikolaus Himmelmanns. Eds, The Austronesian Language of Asia and Madagascar, London \& New York: Routledge, pp. 397 - 428.

Kroeger, P. (2015). Derivational, reduplication, and other delights. FLEx workshop, Universiti Malaysia Sabah.

Kroeger, P. (2015). Tense, mood and voice in other Borneo languages. FLEx workshop, Universiti Malaysia Sabah:

Kroeger, P. (2015). Voice in Philippine-type languages. FLEx workshop, Universiti Malaysia Sabah.

Kroeger, P. (2015). Speaker-oriented particles in Kimaragang Dusun. FLEx workshop, Universiti Malaysia Sabah.

Minah Sintian dan Rosliah Kiting. (2016). Tinimungan Tangon Kadazandusun (Himpunan Cerita Kadazandusun). Tanjong Malim: Penerbit Unversiti Pendidikan Sultan Idris dan Penerbit Universiti Malaysia Sabah.

Mischon Soinggin. (2012). Yoropod. Bahagian Teknologi Pendidikan Negeri Sabah. Kementerian Pendidikan Malaysia.

Payne, Thomas E. (2001). Describing morphosyntax. A guide for field linguists. United Kingdom Cambridge University Press.

Puralan boros Kadazandusun id sikul. (2008). Putrajaya: Bahagian Perkembangan Kurikulum Kementerian Pendidikan Malaysia.

Robinson, L. (2005). A sketch grammar of tindal Dusun. Working Papers in Linguistics, Volume 36 (5), October, Department of Linguistics: University of Hawai'i at Manoa, Honolulu.

Rujukan ringkas aspek linguistik bahasa Kadazandusun. (2007). Penampang: Kadazandusun Language Foundation (KLF). 